$\begin{array}{ll}\text { Abstracta Iranica } & \begin{array}{l}\text { Abstracta Iranica } \\ \text { Revue bibliographique pour le domaine irano-aryen }\end{array} \\ & \text { Volume } \mathbf{2 7} \mid \mathbf{2 0 0 6} \\ & \text { Comptes rendus des publications de } \mathbf{2 0 0 4}\end{array}$

\title{
«Les Séleucides et l'Elymaïde ». Parthica, vol. 6, (2004), pp. 107-115.
}

\section{Rémy Boucharlat}

\section{(2) OpenEdition}

1 Journals

Édition électronique

URL : http://journals.openedition.org/abstractairanica/5802

DOI : 10.4000/abstractairanica.5802

ISSN : 1961-960X

Éditeur :

CNRS (UMR 7528 Mondes iraniens et indiens), Éditions de l'IFRI

\section{Édition imprimée}

Date de publication : 15 mai 2006

ISSN : 0240-8910

\section{Référence électronique}

Rémy Boucharlat, « «Les Séleucides et l'Elymaïde ». Parthica, vol. 6, (2004), pp. 107-115. », Abstracta Iranica [En ligne], Volume 27 | 2006, document 117, mis en ligne le 02 janvier 2007, consulté le 25 septembre 2020. URL : http://journals.openedition.org/abstractairanica/5802 ; DOI : https://doi.org/ 10.4000/abstractairanica.5802

Ce document a été généré automatiquement le 25 septembre 2020.

Tous droits réservés 


\title{
«Les Séleucides et l'Elymaïde ». Parthica, vol. 6, (2004), pp. 107-115.
}

\author{
Rémy Boucharlat
}

L'A. revient sur une question longuement débattue : quelles raisons ont poussé les rois séleucides, Antiochos III en 187 et Antiochos IV en 164 av. J.-C., à tenter de piller des temples d'Élymaïde. La politique religieuse royale étant en général tolérante, des dons étant même offerts aux temples des différentes religions, l'explication traditionnelle des pillages est financière: ils auraient été motivés par le besoin de renflouer la trésorerie royale. E.D. note que de tels actes ont toujours été commis, en Élymaïde comme en Arménie et dans la Basse Mésopotamie, dans le cadre de vastes opérations militaires visant à rétablir l'autorité royale et non pas uniquement pour s'approprier les richesses des temples, encore que cet aspect ne soit pas négligeable. En effet, à la fin de l'empire séleucide, suite à l'échec contre les Romains en Syrie et à la montée de nouveaux pouvoirs, dont celui des Parthes, dans les régions orientales de l'empire, les rois séleucides ont entrepris de vastes campagnes. C'est donc dans un contexte militaire, avec des forces importantes, et selon une stratégie bien mûrie, que les deux Antiochos ont fait campagne en Orient, et, au passage, tenté de piller les temples, sans doute pour marquer les esprits. À cet égard, l'Élymaïde, et particulièrement la zone montagneuse, n'était pas une province lointaine, mais un danger immédiat, à l'est de la Mésopotamie et de Séleucie, l'une des capitales de l'empire.

\section{INDEX}

Thèmes : 3.2.2. Pré-Achéménides et Achéménides 
AUTEURS

RÉMY BOUCHARLAT

IFRI-CNRS - Téhéran-Lyon 